\title{
MOKYKLINIO AMŽIAUS VAIKŲ GYVENIMO YPATUMAI ONKOHEMATOLOGINES LIGOS METU
}

\author{
Laura Petkūnaitė, Justinas Blaževičius, Katrin Kočan, Rolandas Zuoza, Natalja Fatkulina \\ Vilniaus universiteto Medicinos fakulteto Sveikatos mokslu institutas
}

Raktažodžiai: psichoemocinè būklè, savarakiškumas, izometrinè plaštakos raumenų griebimo jèga, fizinio skausmo jutimas, laisvalaikis.

\section{Santrauka}

Tyrimo tikslas - ištirti onkohematologinès ligos sukeliamus ypatumus mokyklinio amžiaus vaiko psichoemocinei būklei, savarankiškumui, fizinio skausmo jutimui, izometrinei plaštakos raumenų griebimo jègai ir laisvalaikio praleidimui. Tyrime dalyvavo 20 mokyklinio amžiaus vaiku, panaudota klinikinè nerimo ir depresijos skalè, funkcinio nepriklausomumo testas, dinamometras, vizualinè skausmo skalè ir kanadietiškas veiklos vertinimo testas. Tyrimo rezultatai parodè, kad nerimas ir depresyvumas tenkina normalią tiriamujjų nuotaiką. Lyginant sveikosios populiacijos ir tiriamujų raumenu jegos rezultatus, tarp berniuku dešinès rankos pastebimas $13 \mathrm{~kg}$, o kairès - $11,8 \mathrm{~kg}$ skirtumas, tarp mergaičių atitinkamai - 7,8 kg ir 7,6 $\mathrm{kg}$. Funkcinio nepriklausomumo testo vidurkis reikšmingai skiriasi nuo normos, o fizinio skausmo jutimo vidurkis $-25,2 \mathrm{~mm}$. Laisvalaikio veiklų atlikimas vertinamas 5,8 balo. Pastebeta, kad didejant atlikimo ivertinimui, pasitenkinimas atliekamomis veiklomis dideja $(r h o=0,961)$. Remiantis tyrimo rezultatais gautos išvados, kad daugiau nei pusès onkohematologinėmis ligomis sergančių mokyklinio amžiaus vaikų (55\%) psichoemociné būklè sutrikusi. Taip pat sergančių pacientų izometrinès plaštakos raumenų griebimo jègos vidurkiai, atsižvelgiant ị tiriamujų amžių ir lytị, mažesni lyginant su sveikaja populiacija, o savarankiškumo lygio įvertinimas svyruoja nuo vidutinès pagalbos poreikio iki visiško savarankiškumo, tiriamieji vidutiniškai patiria nestiprų fizinị skausmą stacionarinio gydymo metu. Laisvalaikis mokyklinio amžiaus vaikams sergant onkohematologine liga tampa pasyvesnis, nei įprastinis, dèl atsiradusių ligos simptomų ir šalutinių gydymo efektų. Laisvalaikio metu atliekamas veiklas ir pasitenkinimą atliekamomis veiklomis tiriamieji vertina vidutiniškai, dažniausia to priežastis - nuovargis.

\section{Ivadas}

Pasaulio sveikatos organizacijos duomenimis, onkologinès ligos yra vienas iš pagrindinių mirtingumo veiksnių [1]. Vaikams ši diagnozè nèra dažna, onkohematologinè liga diagnozuojama dviems šimtams vaikų iš milijono [2].

Onkologinès ligos sukelia psichologinius ir fizinius sutrikimus, dèl kurių mažeja paciento dalyvumas ir aktyvumas [3]. Pastebimos psichologinès problemos (stresas, nerimas, depresyvumas), fiziologinis poveikis (nuovargis, skausmas, pykinimas, vemimas) ir socialinès problemos (atskirtis, vaidmens ir funkcijų praradimas), kurios lemia prastesnę pacientų gyvenimo kokybę. Tokių pacientų gydymo tikslas yra ne tik ligos gydymas ir mirtingumo mažinimas, bet ir fizinių bei psichologinių problemų sprendimas, gyvenimo kokybès pagerinimas [4]. Anot N. Nagy ir kitų (2017), dauguma studijų, susijusių su vaikų onkologinėmis ligomis, skirtų vaikų gyvenimo kokybės tyrimui, neatskleidžia pokyčių, vykstančių vèžiu sergančių vaikų gyvenime.

Nèra pakankamai duomenų apie tai, kaip pasikeičia vaiko psichoemocinè būsena, susirgus onkologine liga. Pasak B. Compaso ir kitų (2014), véžio sukeltas stresas ir psichoemocinès problemos sutrikdo vaiko kasdienę veiklą, dèl to mažèja paciento savarankiškumo lygis, sukeliamas fizinis skausmas, atsiranda nepasitikejimas gydytojais ir mirties baimè. M. Riba (2016) tyrimo metu domejosi, kaip kinta nerimo ir depresijos lygis, sergant onkohematologine liga ir kas lemia šiuos ypatumus. Nèra aišku, diagnozė ar kiti dèl ligos įvykę gyvenimo pokyčiai lemia psichikos sutrikimus. Depresyvumas ir padidejęs nerimo lygis yra aktuali onkologinèmis ligomis sergančių paauglių problema, ịrodyta kiekybiniais ir kokybiniais tyrimais [5]. Svarbu atskleisti ir fizinio skausmo pojūčio pokytį, sužinojus diagnozę. Pasak K. 
Vasquenza (2015), fizinis skausmas - svarbiausias aspektas, kuris daro poveikį gyvenimo kokybei. Skausmo sumažejimas teikia potencialo paciento sveikatos grąžinimui.

Tyrimais dar nepakankamai atskleista, kaip kinta laisvalaikio ypatumai, sergant onkohematologine liga, dažnai ịprastinès veiklos rūšys tampa neįmanomos dèl kilusių bendravimo sunkumų, nes pacientai jaučiasi izoliuoti nuo aplinkinių dèl griežtos hospitalizacijos, kuri varžo galimybes lankyti mokyklą, susitikti su draugais [6]. Nedaug rasta informacijos, kaip kinta izometrinè plaštakos raumenų griebimo jëga, nors raumenu jègos disfunkcija yra klinikinè problema, atsirandanti ligos pradžioje. Didesnè raumenų jẻga gali sušvelninti vėžio poveikị (toksiškumą), pagerinti gyvenimo kokybę ir išgyvenamumą [7].

Dẻl informacijos trūkumo gyvenimo srityse, kurias paveikia onkohematologinè liga, šiuo tyrimu siekiama išsiaiškinti, kaip pakinta vaiko psichoemocinè būklè, fizinio skausmo jutimas, savarankiškumo lygis, plaštakos raumenų jẻga bei laisvalaikis, ir išanalizuota, ar véžys vaikams sukelia ne tik fizines problemas, tačiau paveikia jų psichinę sveikatą ir socialinị gyvenimą.

Tyrimo tikslas. Ištirti onkohematologinès ligos sukeliamus ypatumus mokyklinio amžiaus vaikų psichoemocinei būklei, savarankiškumui, fizinio skausmo jutimui, izometrinei plaštakos raumenų griebimo jègai ir laisvalaiko praleidimui.

\section{Tyrimo medžiaga ir metodai}

Tyrimas atliktas $2017 \mathrm{~m}$. rugsèjo - $2018 \mathrm{~m}$. vasario mènesiais, Vilniuje, Vilniaus universiteto Santaros klinikų (toliau VUL SK) Vaikų ligoninès Onkohematologijos skyriuje. Tirta 20 mokyklinio amžiaus (7-17 m.) vaikų, susirgusių onkohematologine liga 2017 metais: 13 berniukų (65\%) ir 7 mergaitès $(35 \%)$. Patogiosios atrankos būdu atrinkti tiriamieji buvo pakviesti dalyvauti vienos grupès tyrime. I tiriamają grupę pacientai buvo įtraukti remiantis šiais kriterijais: mokyklinis amžius, onkohematologinè liga diagnozuota 2017 metais, gautas tévų (globejų) ir vaiko sutikimas. Tyrimo metu tiriamiesiems buvo taikomas chemoterapinis arba reabilitacinis gydymas. Tyrimo dalyvių amžiaus vidurkis 12,4 $(\mathrm{SN}=3,1)$, dažniausiai pasikartojantis vaikų amžius - 9 metai.

Tiriamųu psichoemocinès būklès, savarankiškumo lygio, skausmo intensyvumo, plaštakos raumenu jègos bei laisvalaikio ịpročiu pokyčiu išaiškinimui taikytas testavimas ir duomenų analizès metodas. Išnagrinètos tyrimo dalyvių ligos istorijos ir atlikta literatūros šaltinių analizè.

Onkologinès ligos poveikis psichoemocinei būklei vertintas naudojant hospitalinę nerimo ir depresijos skalę (toliau - HADS), skirtą ịvertinti bendrojo profilio (ne psichiatrijos) gydymo ịstaigų ligonių depresijos ir nerimo simptomus. Nau- dojant HAD skalę, pacientas, atsižvelgdamas ị savo sveikatą per pastarają savaitę, atsako ị 14 klausimų, vertinamų nuo 0 iki 3 balų. Septyni klausimai skirti depresijos, septyninerimo simptomu vertinimui.

Savarankiškumo lygio pokyčiui vertinti naudotas funkcinio nepriklausomumo testas (toliau - FNT), kurị sudaro 18 vertinamų veiksmų. Vertinimas 7 balų sistema, kurioje 7 balai reiškia visišką savarankiškumą, o 1 balas - reikalinga absoliuti pagalba. Bendra balų suma nuo 18 iki 126.

Plaštakos raumenų jègos kitimui išaiškinti naudotas hidraulins rankos dinamometras. Tai plačiausiai taikomas plaštakos izometrinès griebimo jègos matavimo būdas. Matuojama tris kartus ir išvedamas matavimų vidurkis. Prieš pradedant matuoti įsitikinama, ar tiriamasis suprato, kaip atliekamas judesys, todèl pirmasis rezultatas neregistruojamas ir atliekami dar trys matavimai. Judesị prašoma atlikti iki atsirandant skausmui. Plaštakos raumenų jegga hidrauliniu dinamometru matuojama nuo 0 iki $90 \mathrm{~kg}$.

Fizinio skausmo stiprumo tyrimui naudota vaizdo analogijos skalè (toliau - VAS) ir $100 \mathrm{~mm}$ skaitmeninès analogijos skausmo skalè, kurią sudaro $100 \mathrm{~mm}$ tiesès atkarpa. Jos pradžia reiškia skausmo nebuvimą, o pabaiga - nepakeliamą skausmą. Paciento pažymètas atstumas išreiškia skausmo stiprumą milimetrais nuo 0 iki 100.

Laisvalaikio ịpročiu pokyčiams atskleisti susirgus onkohematologine liga, naudotas modifikuotas kanadietiškas veiklos vertinimo testas (toliau - KVVT). Šis modelis nagrineja tokias veiklos sritis kaip apsitarnavimas (1A dalis), produktyvumas (1B dalis) ir laisvalaikis (1C dalis). Naudota $1 \mathrm{C}$ dalis - laisvalaikis. Vertinta pasvyvus, aktyvus poilsis ir socializacija; išskirtos kiekvienos veiklos rūšies problemos, kurios trukdè pacientui atlikti veiklą ir įvertintas veiklos svarbumas balais nuo 1 iki 10 . Kiekviena problema buvo vertinama pagal atlikimą ir pasitenkinimą, bendras taškų skaičius gautas sudejus visų problemų atlikimo ir pasitenkinimo taškus ir padalinus gautą skaičiu iš problemų skaičiaus.

\section{Rezultatai ir jų aptarimas}

Psichoemocinès būklès ịvertinimą tyrimo metu sudarè atskirai ịvertintas nerimo, depresijos lygis ir bendroji balų

1 lentelè. Psichoemocinès būklès vertinimo kriterijų vidurkiai ir standartiniai nuokrypiai

\begin{tabular}{|l|c|}
\hline $\begin{array}{l}\text { Tyrimo HADS parametras, } \\
\text { balais }\end{array}$ & $\begin{array}{c}\text { Vidurkis ir } \\
\pm \text { standartinis nuokrypis } \\
(\mathbf{n = 2 0 )}\end{array}$ \\
\hline Nerimas & $7,1 \pm 4,9$ \\
\hline Depresija & $3,1 \pm 2,7$ \\
\hline Balų suma & $10,2 \pm 6,6$ \\
\hline
\end{tabular}


suma; pagal bendrają balų sumą ịvertintas bendras nerimo ir depresyvumo jutimas. Išanalizuoti kiekybiniai diskretūs kintamieji - nerimo, depresijos ir bendroji balų suma bei ranginis kategorinis kintamasis - HADS išvada. Šio tyrimo rezultatų vertinimui ir aptarimui aktualu duomenų vidutinès reikšmès bei jų standartinis nuokrypis (1 lentelè).

Gauti rezultatai įrodo, jog dažniausiai tiriamiesiems nepasireiškia nerimui būdingi simptomai, o ịvertinus depresijos balus galima teigti, kad onkohematologinèmis ligomis sergančių mokyklinio amžiaus vaikų nevargina adhedonijos simptomai.

Vertinimo išvadoms gauti normatyvinès ribos skiriasi priklausomai nuo tyrejų ir pasirinktos populiacijos bei jos dydžio. HADS šiame tyrime patikima, nes gautoji Cronbach alpha reikšmė yra 0,789 . Nerimastingumo vertinimui pritaikius T kriterijų vienai imčiai $(\mathrm{Cl}=95 \%)$, gautasis rezultatas parodè, kad vidutine pacientų nerimo išraiška statistiškai reikšmingai nesiskiria nuo 7 balų $(\mathrm{p}=0,929)$. Tai normalus nerimo lygis arba nuotaika, todèl negalima teigti, kad sergant onkohematologine liga vaikų nerimo lygis reikšmingai pakilęs.

Depresijos išraiškai ištirti atlikus Wilcoxon ženklų kriterijaus testą paaiškejjo, kad kintamojo „HADS: depresija (balai)" mediana statistiškai reikšmingai nesiskiria nuo 3,5 balų, nes $p>\alpha(p=0,259)$, todèl depresyvumas, remiantis
J. Burkausku (2013), tenkina normalią tiriamujų nuotaiką. Wilcoxon testu ịvertinus depresyvumą, remiantis I. Bjelland ir bendraautorių (2002 m.) atlikta sistemine apžvalga, gaunama ta pati išvada, kad depresijos vertinimas nesiskiria nuo normos, kai depresijos subgrupeje pasiekiamas $83 \%$ jautrumas ir 79\% specifiškumas. HADS balų sumos vertinimui pritaikius $\mathrm{T}$ kriterijų, paaiškejo $(\mathrm{Cl}=95 \%)$, kad vidutinè HADS balų suma statistiškai reikšmingai didesnè už 7 balus $(p<\alpha, p=0,022)$. F kriterijaus pagalba apskaičiavus HADS balų sumos dispersijas tarp mergaičių $\left(\mathrm{s}^{2}=33,476\right)$ ir berniukų $\left(\mathrm{s}^{2}=46,589\right)$, paaiškejjo, kad dispersijos skiriasi statistiškai nereikšmingai $(\mathrm{p}=0,715)$. Remiantis dviejų imčių $\mathrm{T}$ testu tapo aišku, kad kintamojo „HADS: balų suma (balai)“ vidurkiai tarp berniukų ir mergaičių skiriasi statistiškai nereikšmingai, nes $p>\alpha(p=0,262)$.

Izometrinès plaštakos raumenų griebimo jëgos vertinimo metu pastebėtas natūralus skirtumas tarp kairès ir dešinès rankos. Griebimo jègos vidurkis skiriamas pagal pacientų amžių ir lytị, todèl gautieji duomenys lyginami atsižvelgiant i natūralias lyčių raumenų jègos ypatybes. Sveikosios populiacijos dinamometrijos rezultatai ir onkohematologinemis ligomis sergančių mokyklinio amžiaus vaikų izometrinès plaštakos raumenų griebimo jègos rezultatai pateikiami 2 ir 3 lentelèse.

Galima teigti, kad sergančiųjų onkohematologine liga

2 lentelè. Sergančių berniukų plaštakų dinamometrijos rezultatų lyginimas su sveikaja populiacija

\begin{tabular}{|l|c|c|}
\hline \multicolumn{3}{|c|}{$\begin{array}{c}\text { Dešiniosios plaštakos dinamometrijos } \\
\text { vidurkis, kg (berniukai) }\end{array}$} \\
\hline amžius, m. & $\begin{array}{c}\text { sveikujų } \\
\text { populiacija }\end{array}$ & $\begin{array}{c}\text { sergančiụjų } \\
\text { populiacija }\end{array}$ \\
\hline $6-7$ & 14,7 & 7,8 \\
\hline $8-9$ & 19,0 & 8,6 \\
\hline $10-11$ & 24,4 & 8,7 \\
\hline $12-13$ & 26,6 & 13,9 \\
\hline $14-15$ & 35,1 & 27,3 \\
\hline $16-17$ & 42,6 & 18,1 \\
\hline
\end{tabular}

\begin{tabular}{|l|c|c|}
\hline \multicolumn{3}{|c|}{$\begin{array}{c}\text { Kairiosios plaštakos dinamometrijos } \\
\text { vidurkis, kg (berniukai) }\end{array}$} \\
\hline amžius, m. & $\begin{array}{c}\text { sveikujų } \\
\text { populiacija }\end{array}$ & $\begin{array}{c}\text { sergančiujų } \\
\text { populiacija }\end{array}$ \\
\hline $6-7$ & 13,9 & 7,5 \\
\hline $8-9$ & 17,7 & 7,9 \\
\hline $10-11$ & 21,9 & 6,7 \\
\hline $12-13$ & 25,1 & 11,6 \\
\hline $14-15$ & 29,2 & 22,7 \\
\hline $16-17$ & 35,6 & 16,4 \\
\hline
\end{tabular}

3 lentelè. Sergančių mergaičių plaštakų dinamometrijos rezultatų lyginimas su sveikaja populiacija

\begin{tabular}{|l|c|c|}
\hline \multicolumn{3}{|c|}{$\begin{array}{c}\text { Dešiniosios plaštakos dinamometrijos } \\
\text { vidurkis, kg (mergaitės) }\end{array}$} \\
\hline amžius, m. & $\begin{array}{c}\text { sveikujų } \\
\text { populiacija }\end{array}$ & $\begin{array}{c}\text { sergančiujų } \\
\text { populiacija }\end{array}$ \\
\hline $6-7$ & 12,9 & - \\
\hline $8-9$ & 16,1 & 6,8 \\
\hline $10-11$ & 22,5 & - \\
\hline $12-13$ & 25,8 & 22 \\
\hline $14-15$ & 26,4 & 6,7 \\
\hline $16-17$ & 30,5 & 22,9 \\
\hline
\end{tabular}

\begin{tabular}{|l|c|c|}
\hline \multicolumn{3}{|c|}{$\begin{array}{c}\text { Kairiosios plaštakos dinamometrijos } \\
\text { vidurkis, kg (mergaitės) }\end{array}$} \\
\hline amžius, m. & $\begin{array}{c}\text { sveikujų } \\
\text { populiacija }\end{array}$ & $\begin{array}{c}\text { sergančiujųu } \\
\text { populiacija }\end{array}$ \\
\hline $6-7$ & 12,3 & - \\
\hline $8-9$ & 14,9 & 5 \\
\hline $10-11$ & 20,5 & - \\
\hline $12-13$ & 23,1 & 23,3 \\
\hline $14-15$ & 22,4 & 0,5 \\
\hline $16-17$ & 25,8 & 19,8 \\
\hline
\end{tabular}


mokyklinio amžiaus vaikų izometrinè plaštakos raumenų griebimo jèga mažesnè, nei sveikųų atitinkamo amžiaus vaiku.

Savarankiškumas tyrimo metu vertintas išskiriant FNT rezultatų sumą ir vidurkị. Visų rezultatų sumos vidurkis $105,3(\mathrm{SN}=21)$ balo, gautieji duomenys pasiskirstę nuo 53 iki 126 balų, vidutiniškai savarankiškumas ịvertintas 5,8 balo $(\mathrm{SN}=1,2)$, vadinasi, tiriamieji yra beveik savarankiški, jų atliekamai veiklai reikia daugiau laiko, nei sveikiesiems, arba naudojamos pagalbinès priemonès. Ivertinus FNT patikimumą šiame tyrime, paaiškejjo, jog parinktas testas yra patikimas, nes jo Cronbach alpha 0,951.

Remiantis Wilcoxon testu, gautosios FNT sumos rezultatų mediana statistiškai reikšmingai skirasi nuo 126 balų $(p<0,001)$, kuomet 126 balai būtų riba, reiškianti visiškai savarankiškų asmenų populiacijos medianą. Tyrimo metu gautos FNT sumos rezultatų sklaida ir mediana pavaizduota stačiakampeje diagramoje (1 pav.), kuri rodo, jog yra viena išskirtis, duomenų sklaida didelè ir gautoji mediana skiriasi nuo sveikujų populiacijos medianos.

Wilcoxon testo rezultatai atskleide, kad onkohematologinèmis ligomis sergančių mokyklinio amžiaus vaikų FNT vidurkio mediana statistiškai reikšmingai skiriasi nuo 7 balų $(\mathrm{p}<0,001)$, kuri reikštų, kad asmuo yra visiškai savarankiškas.

Vidutinis fizinio skausmo jutimo ịvertinimas VAS - 25,2 $\mathrm{mm}(\mathrm{SN}=33,2)$, duomenys svyruoja nuo 0 iki 100 milimetrų, todèl galima teigti, kad fizinio skausmo jutimas tarp onkohematologinėmis ligomis sergančių mokyklinio amžiaus vaikų neturi normuotos sklaidos, tačiau vidutiniškai tiriamieji patiria nestiprų skausmą. Ženklų kriterijus parodo, jog skausmo jutimo mediana statistiškai reikšmingai skiriasi nuo $0 \mathrm{~mm}$,

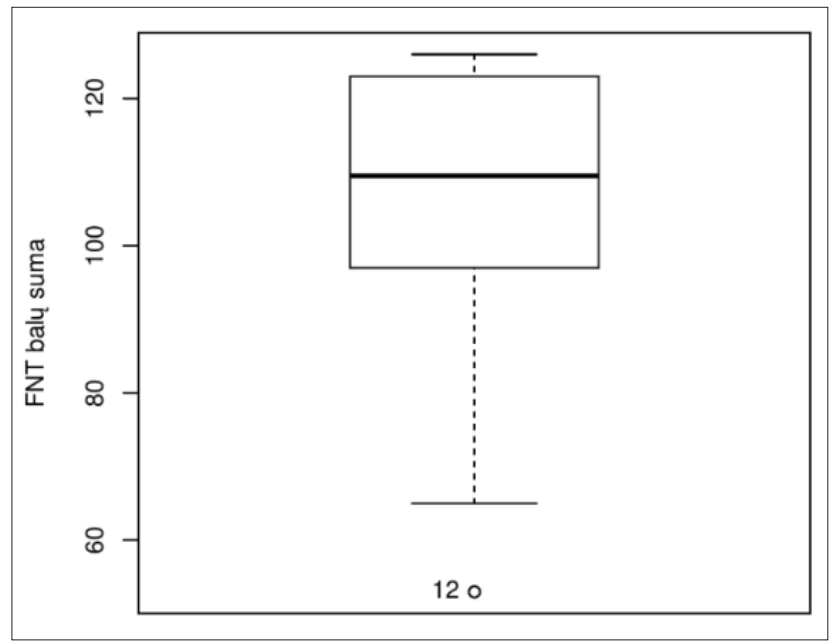

1 pav. FNT balų sumos rezultatų sklaidos stačiakampė diagrama nes $\mathrm{p}<0,000$, gautoji mediana -8 , vidurkis $-25,2 \mathrm{~mm}$, vadinasi, vidutinis onkohematologinėmis ligomis sergančių pacientų fizinio skausmo pojūtis yra $25 \%$ - nestiprus skausmas.

Ivertinus onkohematologine liga sergančių mokyklinio amžiaus vaikų laisvalaiki, paaiškėjo, kad jie savo mėgstamos veiklos atlikimo galimybes vidutiniškai vertina 5,8 balo $(\mathrm{SN}=2,8)$, tai reiškia, kad tiriamieji savo veiklą vertina vidutiniškai. Pasitenkinimas atliekamos veiklos rūšimis įvertintas 4,7 balo $(\mathrm{SN}=2,7)$, todèl galima teigti, kad asmenys yra vidutiniškai patenkinti savo laisvalaikio veiklos atlikimu. Vidutiniškai išskiamos 2,6 problemos ( $\mathrm{SN}=0,8)$, jų skaičius svyruoja nuo 1 iki 5, pastebèta, kad įvardintas mažesnis problemų skaičius neturi poveikio tiriamujų atliekamos veiklos rūšių ir pasitenkinimo jų atlikimu ịvertinimo rezultatui. Dažniausiai įvardintas laisvalaikio užsièmimas - kompiuteriniai žaidimai ir futbolas. Svarbiausi veiklos vykdymo trukdžiai - nuovargis, pykinimas ir raumenų silpnumas.

Patikrinus pasitenkinimo veiklos rūšių atlikimu balų koreliaciją paaiškejjo, kad ji yra statistiškai reikšminga $(\mathrm{p}=1,72 \mathrm{e}-11)$. Didejant atlikimo įvertinimui, pasitenkinimas atliekama veikla taip pat didejja $(r h o=0,961)(2$ pav.). Sudarius tiesinès regresijos lygti, nustatyta, kad norint gauti onkohematologinėmis ligomis sergančių pacientų atliekamų laisvalaikio veiklos rūšių pasitenkinimo įvertinimą, statistiškai reikšmingą koeficientą $(\mathrm{p}=4,7 \mathrm{e}-12$ ) reikia padauginti iš veiklos rūšių atlikimo ịvertinimo balų:

Pasitenkinimas atliekama veikla $=0,94247 *$ veiklos rūšiu atlikimo ịvertinimo.

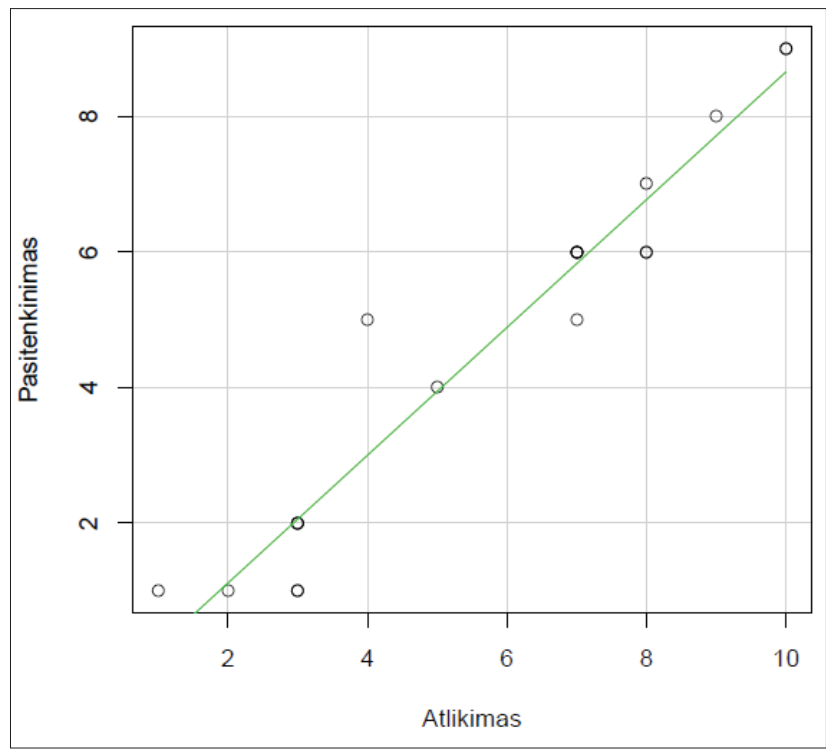

2 pav. Pasitenkinimo veiklos rūšimis ir jų atlikimo ịvertinimo koreliacija 
Regresijos lygtis nėra tinkama duomenų prognozei, nes gautosios paklaidos netenkina normalumo sąlygos $(0,017)$, nors pataisytasis determinacijos koeficientas $\left(\operatorname{adj~} \mathrm{r}^{2}=0.930\right)$ parodo, kad šis modelis tiksliai aprašo priklausomaji kintamaji. Norint tinkamai prognozuoti onkohematologinemis ligomis sergančių mokyklinio amžiaus vaikų pasitenkinimą laisvalaikio veiklos rūšimis, reikalingas tęstinis tyrimas, didinat tiriamujų imtị.

Apklausus dvidešimt mokyklinio amžiaus vaikų, sergančių onkohematologine liga, paaiškèjo, kad jų laisvalaikis pakito, lyginant su laikotarpiu iki ligos. Remiantis subjektyvia anamneze, vaikų aktyvią rekreaciją pakeitė pasyvus poilsis, reikalaujantis mažiau dèmesio koncentracijos, raumenų jëgos ir koordinacijos. Mokyklinio amžiaus vaikai pažymi, kad jiems svarbu laisvalaikis su bendraamžiais ir bendravimas su jais nuotoliniu būdu, esant ligononèje.

\section{Išvados}

1. Daugiau nei pusès $(55 \%)$ onkohematologinèmis ligomis sergančių mokyklinio amžiaus vaikų psichoemocinè būklè sutrikusi $(p=0,022)$. Berniukai dažniausiai patiria vidutinio sunkumo sutrikimus, o mergaičiu nuotaika tenkina nustatytą normos ribą. Atskirai vertinant nerimo ir depresijos simptomus, statistiškai reikšmingų pokyčių nepastebèta.

2. Onkohematologinèmis ligomis sergančių vaikų izometrinès plaštakos griebimo jègos vidurkiai, atsižvelgiant i tiriamujjų amžių ir lytị, mažesni, lyginant su sveikaja populiacija. Didesnis skirtumas pastebimas berniukų populiacijoje.

3. Onkohematolginèmis ligomis sergančių mokyklinio amžiaus vaikų savarankiškumo lygio ịvertinimas svyruoja nuo vidutinès pagalbos poreikio iki visiško savarankiškumo. Dažniausiai vaikams nebūtina kontaktinè pagalba apsitarnaujant, jie yra beveik savarankiški, tik ịvairiai veiklai atlikti reikia daugiau laiko arba pagalbinių priemonių. Šie vaikai vidutiniškai patiria nestiprų fizinị skausmą stacionarinio gydymo metu.

4. Onkohematologine liga sergančių mokyklinio amžiaus vaikų laisvalaikis tampa pasyvesnis, nei ịprastinis, dèl atsiradusių ligos simptomų ir gydymo šalutinio poveikio. Laisvalaikio veiklą ir pasitenkinimą ja tiriamieji vertina vidutiniškai, dažniausia priežastis - nuovargis.

\section{Literatūra}

1. World health organization, 2017. http://www.who.int/ mediacentre/factsheets/fs297/en/

2. Stewart BW, Wild ChP. World cancer report 2014. IARC Press, International Agency for Research on Cancer 2014.

3. Coughtrey A, Millington A, Bennett S, Christie D, Hough R, $\mathrm{Su} \mathrm{MT}$, et al. The effectiveness of psychosocial interventions for psychological outcomes in pediatric oncology: a systematic review. Journal of Pain and Symptom Management 2018;55(3):1004-1017.

https://doi.org/10.1016/j.jpainsymman.2017.09.022

4. Kalibatienė D, Jokubaitienė A. Onkologinių pacientų su sveikata susijusi gyvenimo kokybè. Medicinos teorija ir praktika, 2016;22(4):348.

https://doi.org/10.15591/mtp.2016.056

5. Compas BE, Desjardins L, Vannatta K, Young-Saleme T, Rodriguez EM, Dunn M, et al. Children and adolescent coping with cancer: self-and parent reports of coping and anxiety/ depression. Health Psychol 2014;33(8):853-861.

https://doi.org/10.1037/hea0000083

6. Rekašiūtė E, Banienė I. Literatūros apžvalga: onkologinėmis ligomis sergančių paauglių psichosocialiniai sunkumai. Visuomenès sveikata, 2016;3(74):8-14.

7. Courneya KS, Segal RJ, McKenzie DC, Dong H, Gelmon K, Friedenreich CM, et al. Effects of exercise during adjuvant chemotherapy on breast cancer outcomes. Med Sci Sports Exerc 2014;46:1744-1751.

https://doi.org/10.1249/MSS.0000000000000297

\section{SCHOOL AGE CHILDREN LIFE PECULIARITIES DURING ONCOHEMATOLOGICAL DISEASE L. Petkūnaitė, J. Blaževičius, K. Kočan, R. Zuoza, N. Fatkulina}

Keywords: oncohematological disease, children, psycho-emotional condition, self-sufficiency, isometric hand muscle grabbing strength, sence of physical pain, leisure time.

Summary

The aim of research work. To study the peculiarities of oncohematological disease for the school-age child's psycho-emotional state, self-sufficiency, sense of physical pain, isometric hand muscle grabbing strength and leisure time.

Materials and methods. The study was done in 2017 - 2018, VUL SK branch, children hospital, the division of oncohematology. Subjects - 20 school age children. Hospital Anxiety and Depression Scale, Functional Independence Measure, dynamometer, Visual Analogue Scale and Canadian Occupational Performance Measure were used for research. Statistical analysis was done with MS Office Excel 2013 and R commander x64 3.4.2 programs.

Results. Anxiety $(\mathrm{p}=0,929)$ and depression $(\mathrm{p}=0,259)$ satisfies the normal mood of the subjects, Hospital Anxiety and Depression Scale amount of points is bigger than 7 scores $(p<\alpha, p=0.022)$. When comparing the healthy population and the muscle strength of the test, the difference between the right hand of the boys is 13 $\mathrm{kg}$ and the left one is $11.8 \mathrm{~kg}$, between girls is $7.8 \mathrm{~kg}$ and $7.6 \mathrm{~kg}$. Functional Independence Measure average is different from the norm $(p<0,001)$. The average of sense of physical pain $-25.2 \mathrm{~mm}$. The performance of leisure activities is estimated at 5.8 points. As the performance increases, satisfaction with the activities is increasing $($ rho $=0,961)$.

Conclusions. 1. More than half of schoolage children with oncohematological diseases $(55 \%)$ have a psycho-emotional disorder 
( $\mathrm{p}=0.022$ ). Boys are mostly moderately affected, and girls' mood fits a set norm. No statistically significant changes were observed in the individual assessment of anxiety and depression symptoms. 2 . The average of isometric hand muscle grabbing strength in patients with onco-hematological diseases, taking into account the age and sex of the subjects, is lower than that of the healthy population. A bigger difference is noticeable in the boys population. 3 . The degree of independence of the school-age children with oncohematological diseases ranges from the average need for help to full self-sufficiency. In most cases, children do not need support at the time of contact, they are almost independent, more time is nee- ded for their activities, or auxiliary measures are used. On average, these children experience mild physical pain during stationary treatment. 4. Leisure time in school age children with oncohematological disease becomes more passive than usual due to the emergence of symptoms and side effects of the treatment. The activities performed during the leisure time, and satisfaction are assessed on average by the subjects, mostly due to fatigue.

Correspondence to: petkunaite.1@gmail.com

Gauta 2020-01-23

\section{KVIEČIAME PRENUMERUOTI „SVEIKATOS MOKSLŲ” ŽURNALĄ 2020 METAIS!}

Žurnalas „Sveikatos mokslai” (Index Copernicus, EBSCO host (Academic Search Complete), Gale (Academic OneFile), ProQuest (Ulrich's, Summon), Australia (ERA) 2012 Journal List (ERA ID 34962) skirtas visų specialybių gydytojams, slaugytojams ir kitiems specialistams, spausdina mokslinius straipsnius lietuvių, anglų kalbomis. Reikalavimai straipsniams atitinka mokslo leidiniams keliamus reikalavimus. Žurnalas kioskuose neparduodamas. Žurnalą, kuris leidžiamas kartą per du mènesius, galima užsiprenumeruoti visuose Lietuvos pašto skyriuose, taip pat internetu: www.prenumeruok.lt Prenumeratos kaina nesikeičia: visiems metams - 36 EUR, šešiems mẻnesiams - 18 EUR, keturiems mẻnesiams - 12 EUR, dviem mẻnesiams - 6 EUR. Prenumeratos kodas: 5348. Žurnalo autoriams straipsnių spausdinimas mokamas. 